\title{
Safeguarding inheritance and enhancing the resilience of orphaned young people living in child- and youth-headed households in Tanzania and Uganda
}

Article

Accepted Version

Evans, R. (2012) Safeguarding inheritance and enhancing the resilience of orphaned young people living in child- and youthheaded households in Tanzania and Uganda. African Journal of AIDS Research, 11 (3). pp. 177-189. ISSN 1608-5906 Available at https://centaur.reading.ac.uk/29328/

It is advisable to refer to the publisher's version if you intend to cite from the work. See Guidance on citing.

Published version at: http://www.ajol.info/index.php/ajar/article/view/82237

Publisher: Taylor \& Francis

All outputs in CentAUR are protected by Intellectual Property Rights law, including copyright law. Copyright and IPR is retained by the creators or other copyright holders. Terms and conditions for use of this material are defined in the End User Agreement. 


\section{CentAUR}

Central Archive at the University of Reading

Reading's research outputs online 
Article forthcoming in African Journal of AIDS Research, Special section on 'Children's coping with HIV' edited by Morten Skovdal and Marguerite Daniels

Title of paper: Safeguarding inheritance and enhancing the resilience of orphaned young people living in child- and youth-headed households in Tanzania and Uganda

\author{
Author: Ruth Evans \\ Lecturer in Human Geography \\ Department of Geography \& Environmental Science \\ University of Reading \\ Whiteknights PO Box 227 \\ Reading RG6 6AB \\ UK.
}

Email: R.Evans@reading.ac.uk. Tel. +44 (0)118 3787755. 


\section{Safeguarding inheritance and enhancing the resilience of orphaned young people living in child- and youth-headed households in Tanzania and Uganda}

\section{Abstract}

This paper explores the resilience of orphaned young people in safeguarding the physical assets (land and property) that they inherited from their parents and in sustaining their households without a co-resident adult relative. Drawing on the concept of resilience and the sustainable livelihoods framework, this paper analyses the findings of an exploratory study conducted with 15 orphaned young people heading households, 18 of their siblings and 39 NGO workers and community members in Tanzania and Uganda. The research suggests that inherited land and property represent key determining factors in the formation and viability of child- and youth-headed households in both rural and urban areas. Despite experiences of stigma and marginalisation in the community, social networks were crucial in enabling young people to protect themselves and their property, in providing access to material and emotional resources and in enhancing their skills and capabilities to develop sustainable livelihoods. Support for child- and youth-headed households needs to recognise young people's agency and adopt a holistic approach to their lives that analyses the physical assets, material resources, human and social capital available to the household, as well as individual young people's wellbeing, outlook and aspirations. Alongside cash transfers and material support, youth-led collective mobilisation that is sustained over time may also help to build resilience and foster more supportive social environments that challenge property grabbing and the stigmatisation of child- and youth-headed households.

\section{Key words}

Child-headed and youth-headed households

Asset inheritance

Chronic poverty

Resilience and protective factors

Please reference as: Evans, R. (in press) Safeguarding inheritance and enhancing the resilience of orphaned young people living in child- and youth-headed households in Tanzania and Uganda, African Journal of AIDS Research 
NGO support for orphans and vulnerable children

Qualitative, participatory methods

Tanzania

Uganda

Please reference as: Evans, R. (in press) Safeguarding inheritance and enhancing the resilience of orphaned young people living in child- and youth-headed households in Tanzania and Uganda, African Journal of AIDS Research 


\section{Introduction}

Three decades of the HIV epidemic have led to changing patterns of care and inheritance in eastern and southern Africa (Oleke, Blystad, \& Rekdal, 2005; Drimie, 2003). An estimated 1.3 million children (aged 0-17 years) in Tanzania had lost one or both parents to AIDS in 2009; in Uganda, the figure was 1.2 million children (UNAIDS, 2010). This represents $6 \%$ of children aged under 18 in Tanzania and $7 \%$ of children in Uganda (UNICEF, 2009). Although the majority of orphaned children are cared for within the extended family, the loss of the parental 'middle generation' has led to the emergence of new household forms, such as child- and youth-headed households where siblings live together independently without a co-resident adult relative (Foster, Makufa, Drew, \& Kralovec, 1997).

Studies in Rwanda (Thurman, Snider, Boris, Kalisa, Nyirazinyoye, \& Brown, 2008), Tanzania and Uganda (Luzze \& Ssedyabule, 2004; Evans, 2011), Zimbabwe (Germann, 2005; Francis-Chizororo, 2008) and Namibia (Ruiz-Casares, 2009) reveal the poverty, stigma and marginalisation child- and youth-headed households may face. Research with orphaned children suggests that their inheritance rights may be denied (Van Blerk, Ansell, Robson, Hadju \& Chipeta, 2008), although few studies explicitly focus on these issues. The stigma surrounding AIDS and children's weak socio-economic position in the community are identified as factors that contribute to their difficulties in safeguarding their deceased parents' land and property (Evans, 2005; Rose, 2007; Drimie, 2003).

Research also recognises young people's resilience and agency in adopting coping strategies in child- and youth-headed households. Researchers have increasingly called for children's and families' experiences to be conceptualised from a resilience perspective, in order to help understand individual differences in dealing with adversity, managing caring responsibilities and exiting from or avoiding chronic poverty (Becker 2007; Evans 2005; Boyden with Cooper, 2007). Resilience is defined as "an individual's capacity to recover from, adapt to, and/or remain strong in the face of adversity" (Boyden with Cooper, 2007: 1). The concept of resilience orphaned young people living in child- and youth-headed households in Tanzania and Uganda, African Journal of AIDS Research 
emphasises people's strengths in coping with adversity and their agency in engaging with protective factors that may help to reduce their vulnerability (Rutter, 1990).

\section{Conceptual framework}

The sustainable livelihoods framework developed by Chambers and Conway (1992) has informed approaches to poverty alleviation in the global South since the 1990s. This framework adopts a holistic approach to people's livelihoods, viewing these as encompassing the capabilities, assets and activities required to make a living (Chambers \& Conway, 1992). A key component of the sustainable livelihoods framework is the identification of people's access to, and use of, a range of assets. Assets have been conceptualised in terms of different forms of capital:

- natural capital: land and environmental resources, property rights

- physical capital: property and goods, machines and tools, transport, livestock, food, energy, communications, infrastructure

- human capital: labour resources in household and community, comprised of different genders, ages and generations, health and ability, education, qualifications and skills

- social capital: networks, membership of groups, support mechanisms, trust and reciprocity, diasporic networks, shared cultural and religious values, language and other markers of cultural identity

- financial capital: income, savings, jewellery, access to credit, remittances, pensions (Carney, 1998).

Research informed by the sustainable livelihoods framework suggests that nonmaterial aspects, such as human capabilities and social capital, as well as physical assets and material resources play key roles in building resilience to shocks and stresses (such as sickness, death and environmental shocks) (Ellis \& Mdoe, 2003). The 'actor-orientated' local focus of the sustainable livelihoods framework has however been critiqued for its tendency to downplay structural constraints, such as politics and power, and its failure to engage with processes of economic globalisation, challenges of environmental sustainability and transformatory shifts in rural economies (de Haan, 2007; Scoones, 2009). Furthermore, many studies use Please reference as: Evans, R. (in press) Safeguarding inheritance and enhancing the resilience of orphaned young people living in child- and youth-headed households in Tanzania and Uganda, African Journal of AIDS Research 
the household as the main unit of analysis and give limited consideration to factors that may influence capabilities at the individual level, such as wellbeing and gendered and generational power relations within the household. Despite the prominence of the sustainable livelihoods framework in development policy and research, few studies to date have used this framework to analyse young people's livelihoods or access to assets (Van Blerk et al., 2008). De Haan (2007: 70) calls for a new generation of livelihood studies that consistently includes power relations on individual and meso-macro levels of scale in the analysis.

Following this approach, recent literature has investigated the relationship between intra-household use of, and control of, assets and the intergenerational transmission of poverty (Soto Bermant, 2008). A key defining feature of 'chronic poverty' is its extended duration and people who experience "significant deprivations for a period of five years or more" are more likely to remain poor for much of their lifecourse and pass on their poverty to subsequent generations ('intergenerational transmission of poverty') (Hulme \& Shepherd, 2003: 405). Access to assets is regarded as crucial to ensuring the financial, physical and emotional security of household members in the present and in the future (Soto Bermant, 2008). In much of Sub-Saharan Africa, long standing customary laws underpin social relations at the clan, community and household levels and explicitly privilege men and exclude women from asset ownership and inheritance (Bird \& Espey, 2010). Traditional inheritance practices mean that land and property are usually divided amongst male heirs following the death of a male household head. However, male heirs are also regarded as responsible for the maintenance of widows and children belonging to the family (Armstrong et al., 1995). Gender discriminatory inheritance practices following widowhood or divorce can have major impacts on the socio-economic position and security of women and their children. While a growing literature has revealed gender inequalities in asset inheritance, few studies explicitly address children's inheritance rights and the difficulties they may face in safeguarding assets.

This article seeks to respond to these limitations in the literature through exploring how orphaned young people in Tanzania and Uganda safeguard inherited physical

Please reference as: Evans, R. (in press) Safeguarding inheritance and enhancing the resilience of orphaned young people living in child- and youth-headed households in Tanzania and Uganda, African Journal of AIDS Research 
assets and sustain their own households. Although many of the young people interviewed experienced chronic poverty and some only had precarious access to land and other assets and resources needed to sustain their households (discussed in Evans, 2011; 2012), this paper focuses on young people's resilience in managing their own households and NGO practices that support them. Following an overview of the research methods, I discuss the findings of qualitative participatory data gathered with orphaned young people, NGO staff and community members. Drawing on the sustainable livelihoods framework, I identify key protective factors at the individual, household and community levels and analyse NGO practices that helped to build young people's resilience. In conclusion, I highlight the policy and practice implications.

\section{Research Methods}

Due to the hidden nature of young people's care work, a small purposive sample of young people (aged under 25) who cared for their siblings without a co-resident adult relative were identified through NGOs working in rural and urban areas in Tanzania (Kagera region, Dar es Salaam and Mbeya) and Uganda (Kampala, Mpigi, Mukono, Wakiso and Luwero districts). These regions were selected due to very high levels of orphanhood, differences in NGO approaches and the fact they offer a contrast of rural/urban locations. Mbeya region had the highest rate of orphanhood in Tanzania, where $17 \%$ of children were estimated to be orphans; the figures were $13 \%$ in Dar es Salaam and $11 \%$ in Kagera (TACAIDS et al., 2005). In Uganda, the highest percentage of orphaned children lived in the Central region in 2005 (18\% of children had lost one or both parents) and $15 \%$ of children were estimated to be orphans in Kampala (UBOS, 2006). In the study areas in both Tanzania and Uganda, most ethnic groups follow patrilineal inheritance systems in which male children usually inherit land and other assets and women usually gain usufruct rights to land and property through their father, husband, sons, or other male relatives.

The main characteristics of the NGOs are summarised in Table 1. These organisations were selected to provide insight into a diverse range of approaches to supporting young people and to facilitate recruitment. Since the original focus of the orphaned young people living in child- and youth-headed households in Tanzania and Uganda, African Journal of AIDS Research 
study was on caring roles in child- and youth-headed households ${ }^{1}$, each NGO was asked to identify 2-5 orphaned young people aged under 25 who cared for their siblings without a co-resident adult relative. The means of recruitment via NGOs may have resulted in an atypical sample of particularly vulnerable young people, currently or recently accessing services and external support. However, the difficulties in gaining access to young people with caring roles, who tend to be highly marginalised, made this approach necessary. In practice, some young people had received no or very little support from the organisations that identified them. Thus, the sample reflects a diverse range of experiences of accessing NGO support.

\section{Table 1: Characteristics of NGOs participating in the research}

\begin{tabular}{|c|c|}
\hline $\begin{array}{l}\text { Primary focus of NGO \& } \\
\text { location }\end{array}$ & Characteristics \\
\hline $\begin{array}{l}\text { 1. HIV support } \\
\text { organisation, Mbeya } \\
\text { region, Tanzania }\end{array}$ & $\begin{array}{l}\text { Orphaned and vulnerable children (OVC) support, voluntary counselling } \\
\text { and testing and home-based care for people living with HIV. Project } \\
\text { partner of national Jali Watoto programme for Most Vulnerable } \\
\text { Children, funded by Global Fund for Malaria, TB and HIV/AIDS at the } \\
\text { time of the research. }\end{array}$ \\
\hline $\begin{array}{l}\text { 2. Community-based } \\
\text { rehabilitation for } \\
\text { disabled people, Dar } \\
\text { es Salaam, Tanzania }\end{array}$ & $\begin{array}{l}\text { Support for disabled people and their families, orphaned and vulnerable } \\
\text { children support for HIV-affected families with a disabled family } \\
\text { member.Project partner of national Jali Watoto programme for Most } \\
\text { Vulnerable Children, funded by Global Fund for Malaria, TB and } \\
\text { HIV/AIDS at the time of the research. }\end{array}$ \\
\hline $\begin{array}{l}\text { 3. Psycho-social support } \\
\text { for OVC, Kagera } \\
\text { region, Tanzania }\end{array}$ & $\begin{array}{l}\text { Well established programme of psycho-social support and youth-led } \\
\text { community action for OVC in region. Supported by a range of funders } \\
\text { and partner organisation of REPSSI, a psycho-social support } \\
\text { organisation based in South Africa. }\end{array}$ \\
\hline $\begin{array}{l}\text { 4. Women living with HIV } \\
\text { rights organisation, } \\
\text { Uganda }\end{array}$ & $\begin{array}{l}\text { Well established organisation of women living with HIV working at the } \\
\text { local, regional and national levels with families affected by HIV. } \\
\text { Received funding from United States Agency for International } \\
\text { Development, among other sources. }\end{array}$ \\
\hline $\begin{array}{l}\text { 5. Community-based HIV } \\
\text { support organisation, } \\
\text { central Uganda }\end{array}$ & $\begin{array}{l}\text { Recently established, small-scale community organisation offering } \\
\text { emotional support to HIV-affected families. Largely sustained by } \\
\text { community volunteers at the time of the research. }\end{array}$ \\
\hline
\end{tabular}

In the first phase, 12 semi-structured interviews were conducted with orphaned young people from 8 child-headed households, 3 youth-headed households and 1 skipped generation household (comprised of a grandmother and orphaned children, which later became a child-headed household) (see Tables 2 and 4). In 10 of the 12 interviews, the eldest co-resident sibling who considered that they had the greatest caring responsibilities was interviewed. In one instance, the youngest of three brothers was interviewed, since his older brothers were working at the time. In one

Please reference as: Evans, R. (in press) Safeguarding inheritance and enhancing the resilience of orphaned young people living in child- and youth-headed households in Tanzania and Uganda, African Journal of AIDS Research 
group interview, three eldest siblings considered that they jointly shared responsibility for the household and were interviewed together. Two individual and four group interviews were conducted with a total of 15 project workers from the five NGOs. Three focus groups were conducted in Tanzania; in Mbeya, with six young people with caring responsibilities and three younger siblings; in Nshamba, Kagera region, with five young women who led or participated in a self-defence group ${ }^{2}$; and with five community leaders and NGO staff (see Table 2).

Thematic analysis identified commonalities in young people's experiences of living in child- and youth-headed households, as well as differences according to gender, age, sibling birth order, rural/urban location and country of residence. A short report was written and translated into Kiswahili and Luganda in order to feed back findings to participants.

In the second phase, participatory workshops were held in the three main research locations of Kampala, Nshamba and Mbeya with a total of 33 orphaned young people (15 young people heading households and 18 of their siblings) and 39 NGO workers and community members (see Table 2). Young people living in child-/youthheaded households who had participated in the first phase were invited to participate in a one-day workshop with one or more of their siblings and travel expenses were met/transport arranged through NGO workers. I presented an overview of the preliminary findings, based on thematic analysis of the interview data and used participatory methods, such as ranking of young people's priorities, to discuss the findings further. I sought to involve young people in identifying key messages from the research and priorities for action through the co-production of creative research outputs (art posters and video-recorded drama and song performances). The findings and young people's ranking of priorities, posters and video-recorded performances produced in their locality were presented to NGO staff and community members at a workshop the following day to stimulate discussions on how to improve opportunities and support for young people living in child- and youth-headed households. 
Table 2: Methods used with sample of participants in Tanzania and Uganda

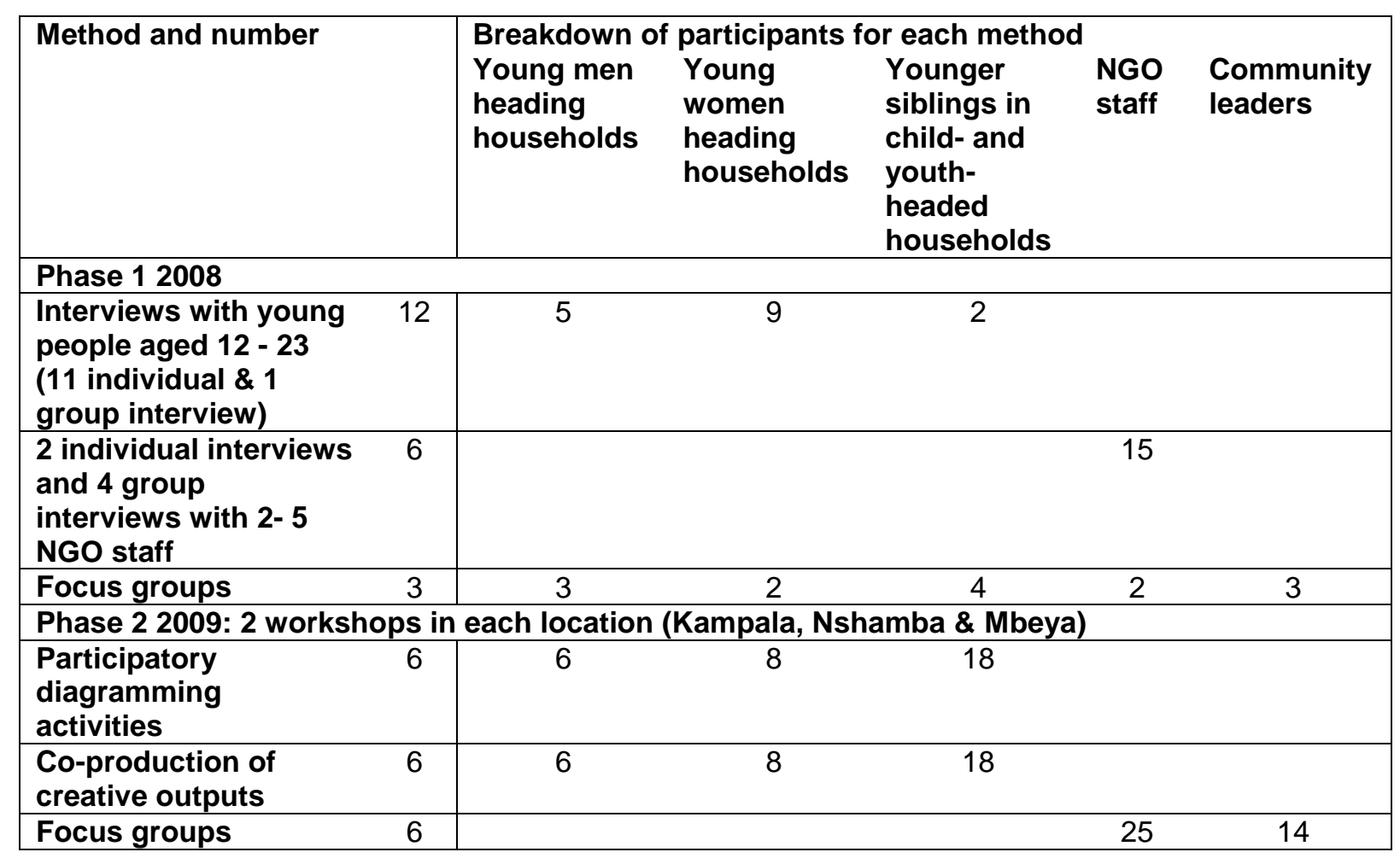

In Tanzania, I conducted the interviews, focus groups and workshops in Kiswahili and the data were transcribed and translated into English with research assistance. In Uganda, interviews were conducted in English with interpretation to/from Luganda provided by NGO workers, although some young people spoke English. Audiorecordings were later transcribed. Workshops were conducted in English and Luganda with research assistance. Informed consent, confidentiality and the safety

Please reference as: Evans, R. (in press) Safeguarding inheritance and enhancing the resilience of orphaned young people living in child- and youth-headed households in Tanzania and Uganda, African Journal of AIDS Research 
and security of the participants and researcher in the collection and storage of the data and dissemination of the findings were of paramount importance throughout the studies $^{3}$. All participants' accounts have been anonymised throughout the paper to protect their identities.

This paper draws in part on analysis conducted for a larger project on asset inheritance and the intergenerational transmission of poverty (see Evans and Day, 2011). The interview transcripts with young people were reviewed and thematically analysed using a template broadly informed by the sustainable livelihoods framework. This provided a holistic summary of each interviewee's access to material and non-material assets and household resources, in addition to their perceptions and experiences of significant events and changes in their lives over time. Key characteristics of the young people interviewed are summarised in Table 4. Visual and audio-visual data gathered in the workshops and interviews and focus groups with NGO workers and community members were also thematically analysed. While this small qualitative sample cannot be seen as representative of child- and youth-headed households in Tanzania and Uganda, it provides insight into a diverse range of experiences of orphaned young people caring for their siblings without a co-resident adult relative and the resources and assets they drew on to manage their lives in communities severely affected by HIV in East Africa.

\section{Table 4: Characteristics of orphaned young people interviewed Please insert Table 4 here (landscape page layout)}

\section{Results and discussion}

\section{Safeguarding inherited physical assets}

Almost all of the young people interviewed had inherited agricultural land, property and/or other assets from their parents, as Table 4 shows. According to conventional inheritance practices in patrilineal societies, paternal relatives would usually keep children's land and other inherited property in trust until they reached the age of majority (Rose, 2007). However, the death of both parents due to AIDS, children's negative experiences of foster care, fear of losing access to their late parents' assets 
and the availability of NGO support resulted in some young people (especially older children) securing control of their land at a younger age than usual. Young people's ownership of land, property and other assets before they are considered to have made 'successful' transitions to adulthood, however, challenges conventional norms of inheritance, household formation and generational relations. This was sometimes sanctioned by property grabbing, stigmatisation, exploitation and accusations of wrong-doing in the community (Evans, 2011).

Young people's experiences suggest that these inherited physical assets were crucial to the formation and viability of child- and youth-headed households. These households appeared to be more common in rural areas due to lower costs of living, the wider availability of land and the livelihood opportunities that access to agricultural land offered in developing food security and providing a source of income. This corresponds to previous findings in Uganda (Luzze \& Ssedyabule, 2004) and Namibia (Ruiz-Casares, 2009). When they inherited property in urban areas, particularly where housing was sufficient both for siblings and for tenants, young people were able to continue living together and earned an income in the informal sector alongside their household care work.

Several young people in Tanzania articulated their transition to heading the household as a shared decision for the siblings to stay together and safeguard their inherited land. Young people's decisions were motivated by a fear of relatives and/or neighbours appropriating their land if they moved away to live with relatives, as well as concerns about fitting in to new routines and being mistreated within foster households. Hamisa (aged 19) feared that she would lose access to her inherited property if she moved away to live with a relative. She requested that a young cousin come to live with her to reduce feelings of loneliness she experienced living on her own: "I thought, I am grown up, if I go to live with them and I am a student, they will grab my properties. How will I start again? I decided to stay here, but I will ask if there is someone who can help me and come to stay here".

Please reference as: Evans, R. (in press) Safeguarding inheritance and enhancing the resilience of orphaned young people living in child- and youth-headed households in Tanzania and Uganda, African Journal of AIDS Research 
Another sibling-headed household was formed following young people's negative experiences of harassment and mistreatment. Johanes (aged 17) and his four younger siblings lived with their aunt and uncle following their parents' death, but found that they were treated differently from their aunt's biological children. The cash transfers they received from an NGO were also misappropriated by their aunt. The siblings decided it was better to move back to their deceased parents' house:

Anita: When our parents first died we lived with our aunt and her children. But then she started to harass us. So it was best for us to move out and live on our own

Johanes: We had to become self-sufficient.

The siblings sought support from NGO workers and their peers to rebuild their inherited home and cultivate their farm.

Orphaned young people in the research locations were regarded as particularly vulnerable to property grabbing following their parents' death. Young people identified the need to address property grabbing and the harassment they experienced as key messages for community members, policymakers and practitioners and developed video-recorded drama stories to show the problems they may experience when relatives or neighbours try to appropriate their inherited home and land. The Kampala drama commenced with children saying together: 'We are children whose parents have died. We don't have anything to eat and there are people who intimidate us. They want to grab our property. We are in a bad situation, we are in a very bad situation!' and the Mbeya drama ended with young people's message:

'We'd like to ask all organisations, we pray to God, for all organisations around the world who safeguard the rights of children to be aware of this problem, to look after children, to be very close to children who have been orphaned, children who have relatives who say that they have come to help 
us, but in fact, they have come to harass us, throw us out of the house and take our property that was left to us by our parents.'

The majority of NGO staff interviewed thought that it was better to support orphaned children to continue living together in their inherited parental property rather than for siblings to move to live with foster relatives. They thought that this helped to strengthen siblings' emotional bonds and enabled them to safeguard inherited assets from unscrupulous relatives who might otherwise sell the children's property. Supporting children to grow up in their inherited parental home was also thought to increase the social inclusion of orphaned children, since they were able to maintain supportive relations with their deceased parents' friends, neighbours and kin in their home communities.

\section{Material resources and external support}

Half of the child- and youth-headed households who had inherited physical assets were able to draw on a range of material and emotional resources, household labour, social networks and external support that enabled them to sustain the household. Young people's narratives reveal how physical assets and material resources combine with other factors to build their resilience. Sophia (aged 21), lived with her three younger siblings (aged 15-19) and her daughter (aged 5) in the property they inherited from their mother in Dar es Salaam. Sophia regarded the house they inherited as crucial to the viability of their sibling household; without a house to live in, she thought that many orphaned siblings would separate and engage in risky activities on the street. Since their mother's death in 2004, the orphaned siblings had received educational support from a HIV NGO and food aid and emotional support from a NGO supporting disabled people. Access to these material resources had enabled Sophia to return to secondary school to study for her Form 4 leaving qualification. The support also enabled the next oldest sister, who had physical impairments and used a wheelchair, to complete Form 4 of secondary school, enabled the third sister to complete primary school (she sold water in the neighbourhood to earn money to support the household) and enabled their younger brother to continue his studies.

Please reference as: Evans, R. (in press) Safeguarding inheritance and enhancing the resilience of orphaned young people living in child- and youth-headed households in Tanzania and Uganda, African Journal of AIDS Research 


\section{Wellbeing, outlook and aspirations}

High aspirations and a positive outlook have been identified as important protective factors for children experiencing adversity (Newman, 2002). The research suggests that young people's wellbeing, including their feelings about their caring responsibilities, their outlook and aspirations for the future, may have a significant influence on their resilience and capabilities. Sophia saw her caring responsibilities as 'normal', once she had adjusted to her changed position within the household following her mother's death:

I have many responsibilities because my siblings need to eat, clothes and different things for their life. So I am the one to think of what to do that will benefit me and my siblings. [...] At the beginning, I saw it as a burden, but now I am used to it and I see it as normal'.

Sophia had high aspirations (she wanted to become a doctor) and was committed to caring for her siblings until they had completed their schooling, emphasising the importance of studying hard, completing secondary school and obtaining a good job to support herself and her siblings in the future. Sophia's sense of wellbeing and positive outlook for the future was, however, linked to accessing continued material support for her and her siblings: 'It is mainly those services that will enable us to reach our life goals, where we will be able to live independently [...] My future life will be very good, and I will be able to support others just like I have been supported'.

In contrast, young people who had very little access to material support, had experienced stigmatisation in the community and/or had lost access to assets such as land and had not been able to continue their schooling, had low aspirations and expressed a sense of hopelessness about the future. Godfrey (aged 17) cared for his three younger brothers and struggled to pay for the rented room where they lived in a village in Luwero district, Uganda by doing casual agricultural labour. Conflict with their uncle meant that the brothers could no longer cultivate food crops on the parcel of land that they used to access. Godfrey did not identify any positive aspects of caring for his brothers, did not feel he could talk to anyone about their problems orphaned young people living in child- and youth-headed households in Tanzania and Uganda, African Journal of AIDS Research 
and although he wanted to train to become a welder or a builder, he tried not to think about this, as he lacked any such opportunities. He felt overwhelmed by his responsibilities in providing for his brothers (via the interpreter): 'He feels painful [pain], because he's not the mother, he's not the father, but he has to take the responsibility, especially on clothing, $\mathrm{mm}$, looking for eats [food], as if he's a parent." When asked how he saw his life in the future, he replied: 'He's not feeling well, there is no future'. Such experiences of chronic poverty, stigma and exclusion compromised young people's wellbeing and restricted their ability to support their siblings and exit poverty traps in the future.

\section{Human capital}

In addition to access to physical and financial assets, material resources and individuals' wellbeing, outlook and aspirations, the human capital available within child- and youth-headed households helped to build siblings' resilience. In the case of Sophia, elements of human capital that appeared to strengthen the siblings' capabilities include: Sophia's age when she started caring for her siblings (17 years) and the fact that her siblings were all aged 10 years or more when their mother died, which meant that they already engaged in many self-care activities ${ }^{4}$; Sophia's previous caring responsibilities (caring for her mother during her illness, for her disabled sister and for her baby) which are likely to have helped to prepare her for sibling caregiving and household headship; shared domestic responsibilities, close loving relationships and a commitment among the siblings to stay together in their inherited home; and the availability of labour resources of siblings who had completed school and could engage in paid work to support the household while other siblings continued their education.

It should be noted, however, that such aspects of human capital could simultaneously be regarded as vulnerability factors for the household. For example: Sophia's curtailed secondary education and limited labour resources due to catching up on studies she was unable to complete when she became pregnant; the young age and care needs of Sophia's daughter; the care needs of her sister who used a 
wheelchair and required assistance with mobility; and the stigma that the siblings experienced within the extended family and community due to their status as a orphan-headed household and Sophia's position as a young, unmarried mother. Sophia found it difficult to find time for private study and sometimes had to miss school due to her caring responsibilities. The household's dependence on her younger sister's insecure, low income in the informal sector and on finite NGO support ${ }^{5}$ could force Sophia to abandon her studies, increasing the likelihood that she would experience chronic poverty over her lifecourse. Furthermore, the fact that the household was headed by a young woman, who would not usually be expected to inherit property due to patrilocal marriage practices, meant that the household was vulnerable to property grabbing if their relatives attempted to appropriate the home the siblings had inherited from their mother. Similar vulnerability and protective factors related to human capital can be identified for the other child- and youthheaded households (see Table 4).

\section{Social capital}

In addition to physical assets, wellbeing, material resources and human capital, the social capital that young people developed represented a crucial factor in building resilience. As previous research shows (Germann, 2005), many young people developed close interdependent relationships with their siblings and strong informal and formal support networks in rural and urban areas. Despite negative experiences of stigmatisation and harassment, orphaned young people often relied on their peers, extended family members, neighbours, community and faith leaders and NGOs for material and emotional support and protection.

Young people emphasised the importance of their friendships and support from their siblings and peers in assisting each other in agricultural or income earning strategies. As Rickson (aged 19, Tanzania) commented:

'We are friends, we stay together, we collaborate on what to do, we ask each other 'how is your life?' We share experiences. [...] We work together [...]. For example, if I have to do weeding in our farm, he comes and helps me, and orphaned young people living in child- and youth-headed households in Tanzania and Uganda, African Journal of AIDS Research 
once we have finished my farm I go to his home and help him as well. For example, during the school holidays, we help each other with different things, like looking for fertilizers'.

Several young people said that they sought advice from neighbours and community leaders in solving conflicts with their younger siblings, as well as seeking protection when they were harassed and threatened with physical and/or sexual violence at night. Developing supportive relations with adult community leaders and support workers could represent an important strategy for young people to protect their property and safeguard their inheritance. The Kampala workshop drama showed the young people seeking legal help from the local council chairperson, who considered the case and upheld young people's inheritance rights. Land rights depend on people's social relations within an ethnic group, family/clan relations, marital relations, friendship, patron-client relations, relations with authorities at various levels of society and so on (Odgaard, 2002: 74). Children's claims to land under customary tenure therefore depend on their status and the social capital they are able to draw on within the community. Community leaders and support workers sometimes played important roles in advocating for orphaned young people's inheritance rights.

\section{Protective factors in safeguarding assets and building resilience}

The analysis indicates that a number of protective factors may significantly reduce the vulnerabilities that child- and youth-headed households face (summarised in Table 5). While none of the households could access all of these resources, young people's life stories suggest that it is the combination of some physical and financial assets, material resources, individual factors (such as age and capabilities when eldest sibling started caring; health and wellbeing, motivations, values and beliefs, outlook and aspirations), relational factors (availability of supportive older siblings/ relatives who can share unpaid and paid work responsibilities, strong social ties) and structural factors (access to education, skills development, healthcare, employment opportunities) that helps to safeguard inheritance and build the resilience of childand youth-headed households.

Please reference as: Evans, R. (in press) Safeguarding inheritance and enhancing the resilience of orphaned young people living in child- and youth-headed households in Tanzania and Uganda, African Journal of AIDS Research 
Table 5: Protective factors in safeguarding inherited assets and building resilience in child- and youth-headed households

\begin{tabular}{|c|c|}
\hline Resources & Examples of protective factors \\
\hline $\begin{array}{l}\text { Physical \& } \\
\text { financial } \\
\text { assets \& } \\
\text { material } \\
\text { resources: }\end{array}$ & 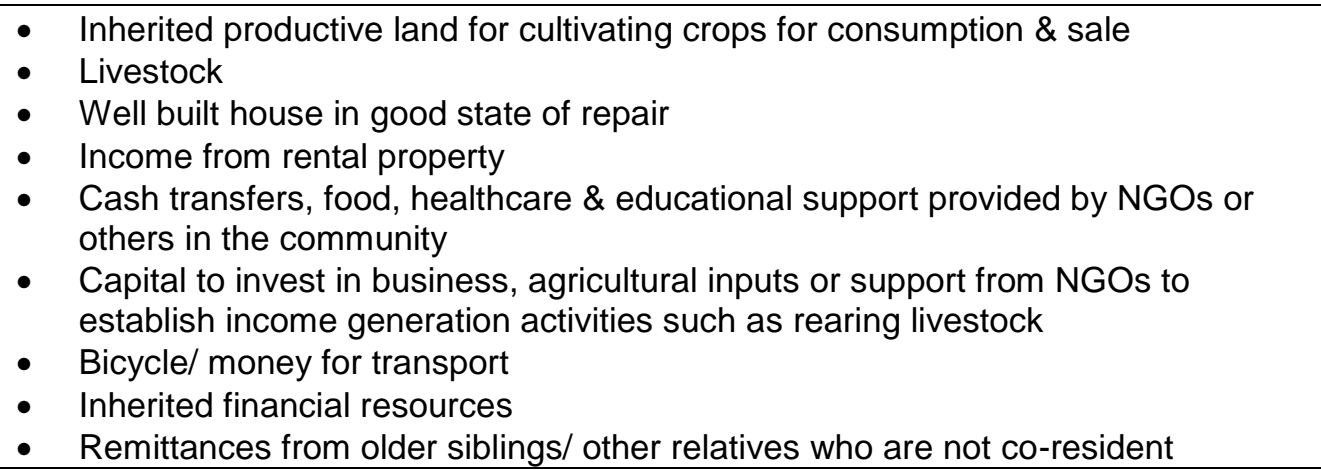 \\
\hline $\begin{array}{l}\text { Human } \\
\text { capital: }\end{array}$ & $\begin{array}{l}\text { - Age when started caring for siblings } \\
\text { - } \quad \text { Previous caring experiences (eg. for a chronically ill parent) } \\
\text { income generation activities } \\
\text { - Willingness of siblings to look after each other \& close loving relationships within } \\
\text { the family } \\
\text { - Opportunities to develop vocational \& life skills in self care, livelihood strategies } \\
\text { \& managing the household, eg. personal hygiene, agriculture, business \& other } \\
\text { income generation activities, budgeting, food preparation, childcare etc. } \\
\text { - Strong value placed on education } \\
\text { - Time for private study \& access to extra tuition }\end{array}$ \\
\hline $\begin{array}{l}\text { Social } \\
\text { capital: }\end{array}$ & $\begin{array}{l}\text { - Practical \& emotional support \& guidance from extended family members, peers, } \\
\text { neighbours, teachers, local leaders \& NGO workers/volunteers } \\
\text { - Opportunities to participate in the community eg. youth groups, faith community, } \\
\text { volunteer work, local celebrations \& events }\end{array}$ \\
\hline $\begin{array}{l}\text { Wellbeing, } \\
\text { outlook \& } \\
\text { aspirations: }\end{array}$ & $\begin{array}{l}\text { - } \quad \text { Siblings in good health \& able to access health care } \\
\text { - Opportunities to share experiences \& feelings with peers in similar situations \& } \\
\text { with supportive adults } \\
\text { - } \quad \text { Positive outlook, clear goals \& aspirations for future } \\
\text { - } \quad \text { Strong religious faith } \\
\text { - } \quad \text { themmitment to care for siblings until they are grown up \& able to support } \\
\text { and neinesilly } \\
\text { and of need to safeguard asset inheritance from unscrupulous relatives }\end{array}$ \\
\hline
\end{tabular}

\section{NGO practices that help to build the resilience of child-and youth-headed}

\section{households}

As noted earlier, material and emotional support from NGOs played a significant role in sustaining the child- and youth-headed households participating in the study, particularly in Tanzania. Analysis of service providers', support workers' and young people's perspectives reveals a number of practices that enhanced young people's capacities to support themselves, such as legal support and advocacy; development

Please reference as: Evans, R. (in press) Safeguarding inheritance and enhancing the resilience of orphaned young people living in child- and youth-headed households in Tanzania and Uganda, African Journal of AIDS Research 
of life skills and livelihood strategies; material, practical, emotional and peer support; and community mobilisation and education.

NGO workers and young people identified legal support, advocacy and education as a key means of assisting orphaned young people to safeguard their deceased parents' assets and challenge cases of property grabbing. Service providers in Tanzania explained how they advocated on behalf of orphaned children who had experienced property grabbing by liaising with neighbours, community leaders at the village and ward levels and if necessary, with the social welfare authorities and lawyers. Education about children's rights, particularly regarding inheritance rights, child abuse and the legal system, was regarded as vital in ensuring that young people were aware of their rights and how they could avoid abuse. Young women leading peer self-defence clubs in Kagera region commented on how useful they had found training about children's rights to protection from sexual abuse and early marriage. They emphasised the need for more education about their rights: 'They were lawyers, they really taught us a lot about how to take the law about child abuse.[..] Because we want to know our rights but we don't know them, we don't understand them. We want more education...'

Many service providers identified the need for young people living in child- and youth-headed households to develop life skills and livelihood strategies. They saw this as a key means of building their resilience to poverty, enhancing food security and preventing them from engaging in risky survival strategies, such as transactional sexual relations and theft, that would expose them to HIV and other sexually transmitted infections or result in community sanction respectively. Young people in Tanzania felt that life skills training they received from NGO workers in budgeting, personal hygiene, conserving food safely and preparing the right amount of food to avoid waste, resolving conflict with their younger siblings and living with others in the community had greatly assisted them in making the transition to caring for their siblings.

Please reference as: Evans, R. (in press) Safeguarding inheritance and enhancing the resilience of orphaned young people living in child- and youth-headed households in Tanzania and Uganda, African Journal of AIDS Research 
NGOs working in rural areas in Tanzania aimed to provide child- and youth-headed households with agricultural inputs such as fertiliser and seeds to improve food security, although funds were limited and staff could usually only assist a few of the most vulnerable households. Project workers highlighted the challenges that young people could face in maintaining their assets if they lacked the means to invest in them: 'Some children have been left with a house and small plots of land, but [...] you tell him to farm but he has no money for seed or fertiliser, so how will he farm? It is true there are some assets, but they have to be facilitated to use them'. Project workers explained that when faced with climatic shocks and the risk of hunger, they tried to prioritise child- and youth-headed households among the many families they supported, due to their higher level of need.

NGO workers suggested that alongside agricultural inputs, young people needed training in developing sustainable livelihoods and enhancing the productivity of their inherited assets, since they were missing out on the informal education and training that their parents would have provided: 'We think that children were [supposed] to get this agricultural education from their parents, now that their parents are not there, then we do help there instead of the parents, to educate children about agriculture'. Indeed, the literature on the impacts of AIDS often expresses concern about the loss of intergenerational transfer of knowledge to orphaned children, particularly regarding agricultural activities (Van Blerk et al, 2008). The evidence for such a loss of the knowledge among orphaned youth is however limited and it has been noted that young people often receive informal training in agriculture and other life skills from a range of peers, adult relatives and community members, not just from their parents (Hadju, Ansell, Robson, Van Blerk, \& Chipeta, 2010).

NGOs in Tanzania provided loans and sometimes capital for young people to start small businesses, such as livestock rearing. Service providers emphasised the importance of starting from young people's perspectives and tailoring support to the individual needs of each young person, since their priorities and livelihood strategies depended on their interests, motivations and the availability of existing assets and resources.

Please reference as: Evans, R. (in press) Safeguarding inheritance and enhancing the resilience of orphaned young people living in child- and youth-headed households in Tanzania and Uganda, African Journal of AIDS Research 
In the workshops, young people collectively ranked the material and emotional needs they had identified in interviews. They saw addressing their basic needs for food, good housing, health care, schooling, bedding and financial support as crucial, before other priorities could be addressed, such as employment and obtaining a regular income or emotional support. Young people saw adequate food as the first priority, with good housing and health care following closely. Many were concerned about the poor quality of housing they lived in, due to their exposure to the cold, rain, mosquitoes and the risk of the house collapsing.

Most NGOs participating in the study provided occasional food aid, educational support and access to healthcare for families affected by HIV, which helped to alleviate the chronic poverty and hunger they experienced, following the reduction in household income due to parental illness or death. Young people in Kagera region received regular cash transfers from an NGO which they highly valued, as it allowed them to budget for their basic needs and concentrate on their schooling without needing to spend so much time engaging in paid work to support the family. While the cash transfers they received were not enough to meet all of their daily needs, young people valued being able to decide how to spend the money themselves according to their requirements. Rickson explained:

'if they had not helped us with this, my life would not have been the way it is now [...] So out of that 15,000 [Tsh.] $]^{6}$, I take 4,000 for porridge and pay. There are other needs [...] if they give us that, we go and buy exercise books. Even food, when it is finished, we buy food and other needs like uniforms, we buy from the money they have given us'.

Such positive experiences of receiving NGO support however raise questions about the sustainability of funding streams for orphans and vulnerable children and how global and national politics of HIV care and support programmes play out at the local level. As noted earlier, NGO support could create dependence on external support 
that is only available in the short and medium term and the withdrawal of such support could increase young people's vulnerability to chronic poverty.

Young people who had access to land were sometimes able to gain assistance from NGO workers and their peers to help prune banana and plantain trees and dig, plant, weed and harvest crops such as maize, potatoes, cassava and beans. NGO workers saw their role as identifying vulnerable households and mobilising young people to assist each other with agricultural labour to improve the household's food security. One project worker explained:

'[The NGO staff and community assistants] recognise that there is a certain child who is caring for himself/herself, and his/her farm condition is not in a good condition. So what we do is to organise those children who are in that cluster on how we can help that child. We plan for a day to go to that family. If they have a banana farm, they remove weeds for him/her...'

Some NGO staff provided practical assistance in renovating young people's homes, arranging childcare to enable young mothers to complete their schooling, collecting medicines and/or providing transport to hospital for children living with HIV.

Orphaned young people, particularly those living in Uganda who were relatively isolated and received little external support, saw emotional and peer support as an important priority, after their basic needs were met. NGO workers supporting siblingheaded households through the Vijana Simama Imara (VSI) [Youth Standing Upright Firmly] youth-led programme in Kagera region saw peer support as crucial in building young people's resilience: 'Some think they have a very heavy burden, but when they hear that their age-mates are also going through the same challenges but have managed to succeed in one way or the other, it encourages him/her'. Young women leading self-defence clubs commented on how such activities helped to build children's confidence to 'stand up for themselves', share their problems and seek support when they were mistreated or their property was stolen:

Please reference as: Evans, R. (in press) Safeguarding inheritance and enhancing the resilience of orphaned young people living in child- and youth-headed households in Tanzania and Uganda, African Journal of AIDS Research 
'After the lessons are over they know how to stand up for themselves. If they meet someone who wants to deceive them or steal something from them they know they can go to a particular place and that there is someone there who can help them, in order for them to keep hold of their things'.

Furthermore, the youth-led VSI programme enabled young people to supplement the financial support they received from the NGO with a small monthly allowance $(1,500$ $\mathrm{Tsh}^{6}$ ) in return for voluntary work for older people in community, such as fetching water and collecting wood. Alongside their allowance, a small amount (300 Tsh) was allocated to the VSI cluster's [village-level youth organisation] communal funds for emergencies, to support orphans and vulnerable children, and to the savings account, which young people collectively decided how to spend. Proceeds from regular auctions of produce also contributed to the village-level VSI orphans and vulnerable children fund. The VSI bank provided a means for young people to save money and take out small loans for individual or collective income-generation activities. An independent evaluation of VSI concluded that the youth-led participative orphan programme was effective in building young people's resilience and resulted in a range of positive outcomes, including developing coping strategies, life skills, social networks with their peers and supportive adults, and making a valued contribution to the community (Clacherty \& Donald, 2006).

Experiences suggest that such youth-led collective mobilisation strategies can also help to challenge the stigma surrounding orphanhood and reduce the marginalisation of child- and youth-headed households (Madoerin, 2008). Several NGO workers highlighted the need for community education in order to raise awareness of the difficulties that children faced, such as stigmatisation, property grabbing and exploitation. They felt that mobilisation helped the community to accept collective responsibility for children caring for themselves and explained that neighbours, volunteers and community leaders were more able to provide on-going advice and guidance to young people than NGOs because of their close proximity to vulnerable households in rural areas:

Please reference as: Evans, R. (in press) Safeguarding inheritance and enhancing the resilience of orphaned young people living in child- and youth-headed households in Tanzania and Uganda, African Journal of AIDS Research 
'We are an NGO but we live far away and we do not live or stay in the villages to be able to see everything that happens. But if the community is educated and have been educated that this is the problem of us all, so that they even supervise how children are brought up, this will at least make it much easier'.

NGO staff collaborated with village and ward-level Orphans and Vulnerable Children/ Most Vulnerable Children Committees, local councils and community leaders, schools and other NGOs where possible. However, they identified the need for greater co-ordination of efforts, communication and information sharing between all stakeholders about policies, implementation and monitoring of interventions to ensure that support reached the most vulnerable children and youth.

\section{Conclusion}

The severity of the HIV epidemic in communities in Tanzania and Uganda means that young people may gain control of valuable physical assets, such as agricultural land, housing and rental accommodation, at a younger age than usual. Such physical assets may represent key determining factors in the formation and viability of child- and youth-headed households in rural and urban areas in Tanzania and Uganda. Despite the risk of property grabbing, harassment and chronic poverty, several child- and youth-headed households demonstrated considerable resilience by safeguarding inherited assets, developing diverse livelihood strategies and building social capital. Orphaned young people who lacked physical assets and external support, in contrast, had often dropped out of school at a young age and worked long hours to earn enough money to support themselves and their siblings. These households experienced food insecurity and hunger and were vulnerable to the intergeneration transmission of poverty. This was evidenced in low educational outcomes which limited human capital in adulthood; the loss of access to or sale of inherited assets (and loss of a stream of future benefits); and the risk of the separation of siblings and dispersal of the household, as young people migrated to urban areas or moved to live with foster relatives, resulting in a weakening of interdependent family ties.

Please reference as: Evans, R. (in press) Safeguarding inheritance and enhancing the resilience of orphaned young people living in child- and youth-headed households in Tanzania and Uganda, African Journal of AIDS Research 
Although social relations with extended family members and others in the community were sometimes detrimental to young people's wellbeing and security, the research highlights the importance of social networks in enabling orphaned young people to protect themselves and their property, in providing access to material and emotional resources and in enhancing their skills and capabilities to develop sustainable livelihoods. These findings challenge widespread assumptions and concerns among development policymakers and practitioners that child- and youth-headed households lack adult guidance and support, lose out on intergenerational transfers of knowledge about livelihoods and other life skills and are disconnected from the wider community (Thurman et al., 2008; Van Blerk et al., 2008).

The research supports the growing literature that argues that unconditional cash transfers and other direct means of providing financial and material support to households have considerable potential to alleviate the chronic poverty that the most vulnerable children and families experience in eastern and southern Africa (Richter, 2010). As Richter (2010) argues, such strategies need to be part of a rights-based long term commitment to social protection that is institutionalised in government-led structures. The research reveals the dangers of creating dependency on external support available only in the short and/or medium term, which may have long term negative consequences for building human capital in child- and youth-headed households when funding streams come to an end. Targeted external support could also undermine the social capital that young people may be able to develop through their relations with friends, neighbours and extended family members and result in resentment and increased stigma in the community. As Thurman et al. (2008) caution, targeting economic assistance only to youth-headed households in poor communities may cause jealousy, aggravating rather than alleviating the marginalisation they experience.

The research shows how youth-led collective mobilisation can facilitate the development of peer support, build young people's resilience and challenge stigma in the community (Madoerin, 2008). Such youth-led approaches can be sustained over time, if older youth, such as the young women leading the self-defence clubs in Please reference as: Evans, R. (in press) Safeguarding inheritance and enhancing the resilience of orphaned young people living in child- and youth-headed households in Tanzania and Uganda, African Journal of AIDS Research 
Kagera region, work with their younger peers to build their capacities to lead groups and facilitate a transfer of knowledge, as they move on to other opportunities.

The findings from Tanzania and Uganda demonstrate the usefulness of the sustainable livelihoods framework as a starting point for the analysis of young people's resilience in safeguarding inherited physical assets and sustaining their households over time. Alongside analysis of access to physical assets and material resources, the research reveals the need to pay attention to individual-level factors, such as age, gender, educational outcomes, health and wellbeing, motivations, outlook and aspirations for the future; human capital, such as household size, age and capabilities of other children, caring relations, health status and disability; and social capital, including social networks, opportunities for participation and wider values, beliefs and norms, such as awareness of HIV, stigma and property grabbing. While this study has focused on the individual, household and community levels, it is important to recognise that orphaned young people are situated within a broader landscape of care in which formal social safety nets are often severely limited, external support is subject to global and local politics of orphanhood and changing donor priorities, and young people's capabilities are constrained by wider structural inequalities in access to education, healthcare and employment opportunities and gender and generational power imbalances.

Young people may inherit a range of assets which vary according to locality, adopt diverse livelihood and coping strategies, and have different interests, motivations and skills. Individually tailored approaches that take a holistic perspective of young people's lives are therefore important for the design and targeting of interventions to support child- and youth-headed households. Support needs to recognise young people's agency, as well as foster peer support and collective mobilisation. Experiences from Tanzania and Uganda suggest that such practices can enhance young people's capacities to care for their siblings and enable them to sustain their households over time, as well as help to build more supportive social environments that challenge stigma and property grabbing and safeguard young people's inheritance.

Please reference as: Evans, R. (in press) Safeguarding inheritance and enhancing the resilience of orphaned young people living in child- and youth-headed households in Tanzania and Uganda, African Journal of AIDS Research 


\section{Notes}

1. The categorisation of households according to 'household headship' has been justifiably critiqued (Chant, 2007; Bell \& Payne, 2009) and I acknowledge that the use of the terms 'child-headed' and 'youth-headed households' is problematic. This research focuses on the experiences and priorities of orphaned young people who cared for their siblings without a co-resident adult relative in what are often termed 'unaccompanied' 'child-headed households' (where there is no co-resident adult and all household members are aged under 18) or 'youth-headed households' (where the 'head' of the household is aged 18-25) (Foster et al., 1997). I recognise that childheaded and youth-headed households occupy a different socio-legal position in terms of inheritance and access to services. Young people's experiences suggest, however, that caring responsibilities, educational and employment status may be more significant markers of difference than biological age-based distinctions between under 18 year-olds and the 18-24 year-old age group. Differences between older siblings' caring responsibilities and those of their younger siblings are discussed elsewhere (Evans, 2011; 2012).

2. Young women who had received training in self-defence techniques and children's rights formed self-defence clubs for girls in their locality, where they taught their younger peers physical self-defence techniques and discussed their rights to protection from violence, abuse and property grabbing and sources of support.

3. The research conforms to the ethical protocols of the Social Research Association and British Sociological Association and ethical approval was granted by the University of Reading's Research Ethics Committee in 2008 and 2009.

4. In the context of children's caring roles in Africa, self-care activities can be defined as, 'Personal care of self, taking medication, getting ready for school, private study, personal development, training, developing life skills and livelihood strategies etc.' (Evans, 2010, p.1481).

5. Funding for the NGO's orphan and vulnerable children support programme was coming to an end at the time of the research.

Please reference as: Evans, R. (in press) Safeguarding inheritance and enhancing the resilience of orphaned young people living in child- and youth-headed households in Tanzania and Uganda, African Journal of AIDS Research 
6. 1 US $\$$ was approximately equivalent to 1150 Tanzanian Shillings when interviews were conducted in 2008.

\section{Acknowledgements}

I wish to thank all the young people, community members and NGO staff in Tanzania and Uganda who participated in the study. I also thank Morten Skovdal, Marguerite Daniels, Laura Lee and the anonymous reviewers for their comments which helped to improve an earlier draft. The research was supported by a Royal Geographical Society (with the Institute of British Geographers) Small Research Grant and by the School of Human and Environmental Sciences, University of Reading. The paper also draws in part on analysis conducted for a Working Paper (Evans \& Day, 2011) of the Chronic Poverty Research Centre (CPRC) which is funded by UKaid from the UK Department for International Development (DFID) for the benefit of developing countries. The views expressed are not necessarily those of DFID. The CPRC gratefully acknowledges DFID's support. Any errors remain the author's own. 


\section{References}

Armstrong, A., Chuulu, M, Himonga, C., Letuka, P., Mokobi, K., Ncube, W., Nhlapo, T., Rwezaura, B., \& Vilakazi, P. (1995) Towards a cultural understanding of the interplay between children's and women's rights: an Eastern and Southern African perspective. The International Journal of Children's Rights, 3, pp. 333-368.

Becker, S. (2007) Global perspectives on children's unpaid caregiving in the family: research and policy on 'young carers' in the UK, Australia, the USA and SubSaharan Africa. Global Social Policy, 7(1), pp. 23-50.

Bell, S., \& Payne, R. (2009) Young people as agents in development processes: reconsidering perspectives for development geography. Third World Quarterly, 30, pp. 1027-44.

Bird, K. \& Espey, J. (2010) Power, patriarchy and land: examining women's land rights in Uganda and Rwanda. In: Chant, S. (ed.) The International Handbook of Gender and Poverty. Edward Elgar Publishing, Cheltenham.

Boyden, J. with Cooper, E. (2007) Questioning the Power of Resilience: Are Children Up To the Task of Disrupting the Transmission of Poverty? CPRC Working Paper No. 73. Manchester, Chronic Poverty Research Centre.

Carney, D. (ed.) (1998) Sustainable Rural Livelihoods: What contribution can we make? London, Department for International Development.

Chambers, R., \& Conway, G. (1992) Sustainable rural livelihoods: practical concepts for the 21st century. IDS Discussion Paper No. 296. IDS, Brighton.

Chant, S. (2007) Dangerous equations? How female-headed households became the poorest of the poor: causes, consequences and cautions. In: Cornwall, A., Harrison, E. \& Whitehead, A. (eds.) Feminisms in Development: Contradictions, Contestations and Challenges. London, Zed Books, pp.35-47.

Clacherty, G. \& Donald, D. (2006) Impact Evaluation of the VSI (Vijana Simama Imara) organisation and the Rafiki Mdogo group of the HUMULIZA orphan project, Nshamba, Tanzania. Novartis Foundation for Sustainable Development and REPSSI.

Drimie, S. (2003) HIV/Aids and Land: case studies from Kenya, Lesotho and South Africa. Development Southern Africa 20(5), pp. 647-658.

Please reference as: Evans, R. (in press) Safeguarding inheritance and enhancing the resilience of orphaned young people living in child- and youth-headed households in Tanzania and Uganda, African Journal of AIDS Research 
Ellis, F. \& Mdoe, N. (2003) Livelihoods and rural poverty reduction in Tanzania. World Development 31 (8), pp. 1367-1384.

Evans, R. (2005) Social networks, migration and care in Tanzania: caregivers' and children's resilience in coping with HIVI AIDS. Journal of Children and Poverty 11(2), pp. 111-129.

Evans, R. (2010) Children's caring roles and responsibilities within the family in Africa. Geography Compass 4(10), pp. 1477-1496.

Evans, R. (2011) "We are managing our own lives...": Life transitions and care in sibling-headed households affected by AIDS in Tanzania and Uganda. Area 43 (4), pp. 384-396.

Evans, R. (2012) Sibling caringscapes: time-space practices of caring within youthheaded households in Tanzania and Uganda. Geoforum, 43, pp.824-835.

Evans, R. \& Day, C. (2011) Inheritance, poverty and HIV/AIDS: experiences of widows and orphaned youth heading households in Tanzania and Uganda. CPRC Working Paper 185. Chronic Poverty Research Centre, Manchester.

Foster, G., Makufa, C., Drew, R. \& Kralovec, E. (1997) Factors leading to the establishment of child-headed households: the case of Zimbabwe. Health Transition Review Supplement 2, 7, pp. 155-68.

Francis-Chizororo, M. (2008) The formation, constitution and social dynamics of orphaned child-headed households in rural Zimbabwe in the era of HIVIAIDS pandemic. Unpublished PhD thesis. School of Geography and Geosciences University of St. Andrews, Scotland.

Germann, S. (2005) An exploratory study of quality of life and coping strategies of orphans living in child-headed households in the high HIVIAIDS prevalent city of Bulawayo, Zimbabwe. Unpublished PhD thesis. University of South Africa. de Haan, L. (2007) Studies in African livelihoods: current issues and future prospects. In: Chabal, P., Engel, U. \& de Haan, L. (eds.) African Alternatives. Koninklijke Brill NV, Leiden, The Netherlands, pp.59-72. Hadju, F., Ansell, N., Robson, E., Van Blerk, L., \& Chipeta, L. (2010) Incomegenerating activities for young people in southern Africa: exploring AIDS and other constraints. The Geographical Journal doi: 10.1111/j.1475-4959.2010.00381.x 
Hulme, D. \& Shepherd, A. (2003) Conceptualising Chronic Poverty. World Development 31(3), pp. 403-423.

Luzze, F. \& Ssedyabule, D. (2004) The Nature of Child-Headed Households in Rakai District, Uganda. Kampala, Lutheran World Federation.

Madoerin, K. (2008) Mobilising Children and Youth into their Own Child- and Youthled Organisations. Johannesburg, REPSSI.

Newman, T. (2002) Promoting Resilience: a Review of Effective Strategies for Child Care Services. Exeter, Centre for Evidence-based Social Services, University of Exeter and Barnardo's.

Odgaard, R. (2002) Scrambling for Land in Tanzania: Process of formalisation and legitimisation of land rights. European Journal of Development Research 14(2), pp. 71-88.

Oleke, C., Blystad, A. \& Rekdal, O. (2005) 'When the obvious brother is not there': political and cultural contexts of the orphan challenge in northern Uganda. Social Science and Medicine 61, pp. 2628-2638.

Richter, L. (2010) Social cash transfers to support children and families affected by HIV/AIDS. Vulnerable Children and Youth Studies No. S1, 5, pp. 81-91.

Rose, L. (2007) Children's Property and Inheritance Rights, HIV and AIDS and Social Protection in Southern and Eastern Africa. HIV/AIDS Programme Working Paper 2. Food and Agriculture Organization of the United Nations, Rome.

Ruiz-Casares, M. (2009) Between adversity and agency: child and youth-headed households in Namibia. Vulnerable Children and Youth Studies 4(3), pp.238-248.

Rutter, M. (1990) Psychosocial resilience and protective mechanisms. In: Rolf, J., Masten, A., Cicchetti, D. Nuechterlein, K. \& Weintraub, S. (eds.) Risk and Protective Factors in the Development of Psychopathology. Cambridge, Cambridge University Press, pp.181-214.

Scoones, I. (2009) Livelihoods perspectives and rural development. The Journal of Peasant Studies 36(1), pp.171-196.

Soto Bermant, L. (2008) Intrahousehold asset dynamics and its effect on the intergenerational transmission of poverty: a select annotated bibliography and literature review. Working Paper No. 115. Manchester, Chronic Poverty Research Centre.

Please reference as: Evans, R. (in press) Safeguarding inheritance and enhancing the resilience of orphaned young people living in child- and youth-headed households in Tanzania and Uganda, African Journal of AIDS Research 
Tanzania Commission for AIDS (TACAIDS), National Bureau of Statistics (NBS) and ORC Macro (2005) Tanzania HIV/AIDS Indicator Survey 2003-04, Calverton, Maryland, USA: TACAIDS, NBS and ORC Macro.

Thurman, T., Snider, L., Boris, N., Kalisa, E., Nyirazinyoye, L., Brown, L. (2008) Barriers to the community support of orphans and vulnerable youth in Rwanda. Social Science and Medicine 66, pp.1557-1567.

UBOS (2006) Uganda National Household Survey 2005/2006, Report on the SocioEconomic Module. Kampala: Uganda Bureau of Statistics.

UNAIDS (2010) Global Report: UNAIDS Report on the Global AIDS Epidemic 2010. New York, Joint United Nations Programme on HIV/AIDS (UNAIDS).

UNICEF (2009) The State of the World's Children 2010. Celebrating 20 years of the Convention on the Rights of the Child. New York, UNICEF.

Van Blerk, L., Ansell, N., Robson, E., Hadju, F. \& Chipeta, L. (2008) Youth, AIDS and rural livelihoods in Southern Africa. Geography Compass 2(3), pp. 709-727. 